\title{
Economic Valuation of Tourism with Travel Cost Method in Beach Tourism, Kolbano Village, Kolbano
}

\author{
Hapsa Usman*, Nonce Farida Tuati, Deetje Wieske Manuain \\ Accounting Department \\ Kupang State Polytechnic \\ Kupang, Indonesia \\ *hapsagemini1978@gmail.com, nonc3tuati@yahoo.com,decewm@yahoo.com
}

\begin{abstract}
Kolbano Beach is located in Kolbano Village, Kolbano District, South Middle East Regency. Kolbano beach is one of the tourist beaches that has an attraction to be used as a tourist attraction. The benefits provided by Kolbano beach are not economically measurable, so it is important to study the magnitude of the economic value of the tourist area. The purpose of this study is to determine the potential and economic valuation value of Kolbano Beach. In August 2020, the research was conducted at Kolbano Beach. This research uses a descriptive method. Data collection obtained through interviews with 100 tourists and one tour manager using a questionnaire with an accidental sampling technique. The tourism economic valuation analysis uses the Travel Cost Method approach. The potential possessed by Kolbano Beach includes the beauty and condition of the beach's attractiveness, including in the excellent category, inadequate facilities and infrastructure, fairly good management services, and the potential for community cultures such as traditional ceremonies and tourist events. The economic value of Kolbano Beach is Rp. 10,610,286,500.00 / year with an average individual travel cost of Rp. 573,529.00 / visit.
\end{abstract}

Keywords-economic valuation, tourism potential, travel cost method

\section{INTRODUCTION}

The coastal area is the border area between land and sea, consisting of various ecosystems and resources. Coastal areas are widely used for human activities such as settlements, industry, ports, aquaculture and tourism. The beach is one of the ecosystems on the coast that has an attraction to be a tourist attraction.

Kolbano Beach is located in Kolbano Village, Kolbano District, South Middle East Regency. Kolbano beach is one of the tourist beaches that has an attraction to be used as a tourist attraction. The benefits provided by Kolbano beach have not been measured economically, so it is important to study the economic value of the tourist area. Kolbano beach is located in Kolbano Village, Kolbano District, South Central East Regency. This beach is about $148.6 \mathrm{~km}$ from Kupang City.

According to Mayasari [1], Kolbano Beach has a potential tourist attraction for many tourists, both domestic and foreign tourists. The economic value of using beach tourism as a tourist attraction is often overlooked, so that data on quantitative economic value is still lacking or even missing. The economic value of a tourist area can be calculated using the travel cost method. The basic premise of the travel cost method is that an individual's time and travel costs to visit a location represent the price for accessing that place.

According to Idris [2], this economic assessment is essential because the information obtained from this assessment will influence the decisions that will be taken regarding the use of this tourism in the future. Decision making for the development and management of the Kolbano Beach tourist area is also influenced by the typology of tourists who visit. Typology of tourists will produce perceptions about a tourist area so that it can be used to determine the development and management strategy of a tourist area. This study aims to determine the tourism potential of Kolbano Beach and determine the economic value of marine tourism in Kolbano Beach based on travel costs (Travel Cost Method) issued by tourists for one visit.

\section{RESEARCH METHODS}

The research method used is a descriptive case study. According to Margareta [3], the descriptive method is a research method used to describe problems in the present or ongoing, aiming to describe what should have happened when the research was carried out. Data Collection Methods The data used in this study consisted of primary data and secondary data. Primary data were obtained through interviews using questionnaires to tourists and tour managers. Secondary data were obtained through literature study, digging information from related agencies, and other supporting literature. Data collection was carried out at Kolbano Beach, South Middle East Regency. The research is shown in Figure 1 Kolbano Beach Tourism Map. 


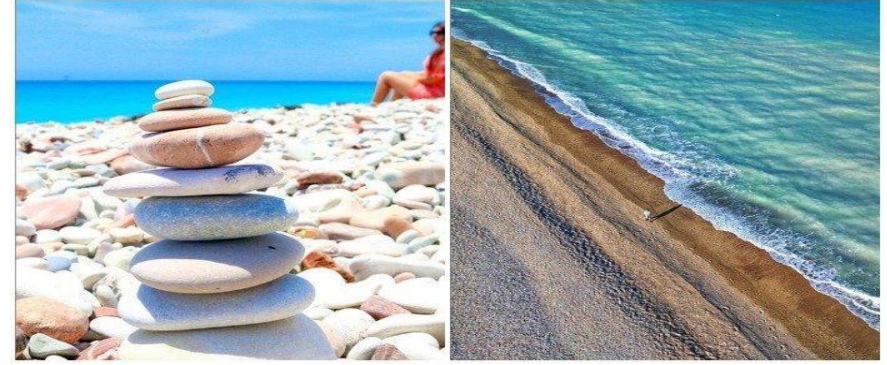

Fig. 1. Kolbano tourist beach.

Method of Determination of Respondents of tourist visitors is taken using the Accidental Sampling technique. Determination of the number of respondents using the Slovin method. The formula for the Slovin method to determine the number of samples is as follows:

$$
n=\frac{N}{1+N(e)}
$$

Data Analysis Method Travel Cost Method The economic value of Kolbano Beach can be estimated using the Travel Cost Method by calculating the cost of transportation, consumption, entrance tickets, and other expenses. The stages in determining the economic value of tourism using the travel cost method are 1. They are determining the number of tourist visits per year based on visitor data in the previous year from natural tourism object managers 2. Estimating the percentage of tourists from each administrative area formulated by Sulistyono [4]: $\mathrm{Pi}=$ JciNx $100 \%$ Where: $\mathrm{Pi}=$ percentage of tourists from each area $\mathrm{i}$; Jci $=$ number of tourists from area $\mathrm{i} ; \mathrm{N}=$ total number of tourists 3. Determine the total amount of travel costs incurred during travel or recreational activities, formulated by Sulistyono [4] with a modification: $\mathrm{BPT}=\mathrm{BT}+\mathrm{BK}+\mathrm{BTk}+$ $\mathrm{BW}+\mathrm{BL}(\mathrm{Rp} /$ person) Note: $\mathrm{BPT}=$ Cost Total Trip; $\mathrm{BT}=$ Transportation Costs; $\mathrm{BK}=$ Cost of consumption during tourist activities; BTk = Ticket and parking fees; BW = Vehicle Fee; $\mathrm{BL}=$ Other Costs Tourists' Perceptions Tourist perceptions were analysed by providing a questionnaire to assess the conditions of tourist attractions, tourist attraction facilities, tourism object management services and the desire to come back. The questionnaire uses a rating of 1-5 with a description of the value 1: Very poor, 2: Not good, 3: Good enough, 4: Good, 5: Very good. According to Pramudhito in Prayudha et al. [5] that the level visitor convenience can be systematically formulated as follows: $\mathrm{NN}=\mathrm{RbSrx} 100 \%$ Information: $\mathrm{NN}=$ Comfort Value in percent; $\mathrm{Rb}=$ Number of respondents who strongly agree and agree $\mathrm{Sr}=$ Number of all respondents Value (score) of comfort:> 80\% = very good $20-39 \%=$ not good 60 $-79 \%=\operatorname{good}<20 \%=$ very bad $40-59 \%=$ not good .

\section{RESULTS AND DISCUSSION}

\section{A. Overview of the Research Location}

Kolbano Beach is located in Kolbano Village, Kolbano District, South Middle East Regency. The area of Jepitu Village is $16.75 \mathrm{~km}^{2}$. The total population of Kolbano Village is 4415 people, consisting of 2015 men and 2400 women [6].

1) Potential of Kolbano Beach: Based on research with the number of respondents 100 tourists, the results obtained regarding tourists' perceptions of the potential of Kolbano Beach tourism object presented in Table 1.

TABLE I. POTENTIAL OF KOLBANO BEACH

\begin{tabular}{|c|c|c|c|c|c|c|c|}
\hline \multirow[t]{2}{*}{ No } & \multirow[t]{2}{*}{ Tourism Potential } & \multicolumn{5}{|c|}{ Value } & \multirow[t]{2}{*}{ Score } \\
\hline & & 1 & 2 & 3 & 4 & 5 & \\
\hline & $\begin{array}{l}\text { Conditions of tourist } \\
\text { attraction } \\
\text { a. The beauty of the } \\
\text { beach } \\
\text { b. Cleanliness } \\
\text { c. Rock/coral clusters } \\
\text { d. Lagoon } \\
\text { e. White sand } \\
\text { f. Seawater }\end{array}$ & $\begin{array}{l}0 \\
0 \\
0 \\
40 \\
0 \\
0\end{array}$ & $\begin{array}{l}0 \\
5 \\
0 \\
38 \\
0 \\
0\end{array}$ & $\begin{array}{l}4 \\
30 \\
18 \\
10 \\
0 \\
4\end{array}$ & $\begin{array}{l}46 \\
40 \\
60 \\
7 \\
60 \\
47\end{array}$ & $\begin{array}{l}50 \\
35 \\
22 \\
5 \\
40 \\
49\end{array}$ & $\begin{array}{l}100 \\
100 \\
100 \\
100 \\
100 \\
100\end{array}$ \\
\hline & $\begin{array}{l}\text { Tourism Object } \\
\text { Facilities } \\
\text { a. Toilet } \\
\text { b. Prayer room } \\
\text { c. Access road } \\
\text { d. Parking area } \\
\text { e. Restaurant and } \\
\text { culinary } \\
\end{array}$ & $\begin{array}{l}80 \\
90 \\
6 \\
3 \\
80\end{array}$ & $\begin{array}{l}20 \\
10 \\
9 \\
7 \\
20\end{array}$ & $\begin{array}{l}0 \\
0 \\
25 \\
26 \\
0\end{array}$ & $\begin{array}{l}0 \\
0 \\
54 \\
44 \\
0\end{array}$ & $\begin{array}{l}0 \\
0 \\
6 \\
20 \\
0\end{array}$ & $\begin{array}{l}100 \\
100 \\
100 \\
100 \\
100\end{array}$ \\
\hline & $\begin{array}{l}\text { Tourism Object } \\
\text { Management Services } \\
\text { a. Friendly } \\
\text { b. Prompt and ethical } \\
\text { c. Informative and } \\
\text { initiative }\end{array}$ & $\begin{array}{l}0 \\
0 \\
15\end{array}$ & $\begin{array}{l}5 \\
4 \\
20\end{array}$ & $\begin{array}{l}15 \\
25 \\
23\end{array}$ & $\begin{array}{l}60 \\
50 \\
30\end{array}$ & $\begin{array}{l}20 \\
21 \\
12\end{array}$ & $\begin{array}{l}100 \\
100 \\
100\end{array}$ \\
\hline & Desire to come back & 6 & 14 & 20 & 36 & 24 & 100 \\
\hline
\end{tabular}

Scale: 1 worst, 2: bad, 3: good enough, 4: good, 5: Excellent.

2) Profile and typology of Kolbano Beach tourists: The majority of Kolbano Beach visitors who became respondents were middle and upper-class people, university students, and students. Most of the tourists who visit come from the city of Kupang. Tourists visit Kolbano Beach as the main tourist destination for a vacation with friends and family. Economic Valuation Determination of the economic value of the Kolbano Beach tourist attraction can be calculated using the Travel Cost Method approach. The travel costs studied included transportation costs, entrance fees, consumption costs, lodging costs, toilet fees, souvenirs/souvenirs, travel costs, and toilet fees. Tourist travel costs vary based on the region of origin. The average travel costs for Kolbano Beach respondents according to their origin, are presented in Table 2. Based on the calculation of the average travel costs of tourists based on the origin of the region, it is known that the highest travel costs came from the city of East Sumba, namely Rp. 800,000 / visit. 
The Lowest Cost of travel for tourists comes from Soe City, which is IDR 100,000 / visit. The average individual Cost per visit is obtained from the results for the total average travel cost by the number of regions to obtain a result of Rp. 573,529.00. The determination of economic value based on average travel costs is presented in Table 3. Based on Table 3, it can be seen that the estimated value of the economy of the Kolbano Beach tourist attraction from the product of the average individual travel cost of Rp.573,529, assuming the number of visitors using visitor data in 2019 is 18,500 people. The results of the economic value of Kolbano Beach were IDR 10,610,286,500.

TABLE II. AVERAge Travel Costs By Region

\begin{tabular}{|l|l|l|c|}
\hline No. & \multicolumn{1}{|c|}{ Region } & $\begin{array}{c}\text { Number } \\
\text { of } \\
\text { tourists }\end{array}$ & $\begin{array}{c}\text { The } \\
\text { average } \\
\text { amount of } \\
\text { Travel cost } \\
\text { (Rp) }\end{array}$ \\
\hline & Kota Kupang & 20 & 500.000 \\
\hline & Larantuka & 5 & 600.000 \\
\hline & Atambua & 10 & 200.000 \\
\hline & Kefamenanu & 10 & 150.000 \\
\hline & Kota Soe & 15 & 100.000 \\
\hline & Labuan Bajo & 2 & 800.000 \\
\hline & Kabupaten Kupang & 10 & 400.000 \\
\hline & Ende & 2 & 800.000 \\
\hline & Nagakeo & 1 & 800.000 \\
\hline & Manggarai & 3 & 800.000 \\
\hline & Lembata & 5 & 500.000 \\
\hline & Rote & 6 & 500.000 \\
\hline & Sabu & 5 & 500.000 \\
\hline & Sumba Timur & 2 & 800.000 \\
\hline & Sumba Barat Daya & 1 & 800.000 \\
\hline & Sumba Barat & 1 & 800.000 \\
\hline & Sumbawa & 2 & 800.000 \\
\hline Total & 100 & 9.750 .000 \\
\hline Average individual costs/visit & 573.529 \\
\hline
\end{tabular}

Source: Primary Data 2020

TABLE III. ECONOMIC VALUES BASED ON 2019 AVERAGE TRAVEL Costs

\begin{tabular}{|l|l|l|l|}
\hline Code & \multicolumn{1}{|c|}{ Variable } & \multicolumn{1}{|c|}{ value } & \multicolumn{2}{|c|}{ Information } \\
\hline $\mathrm{A}$ & $\begin{array}{l}\text { Average } \\
\text { Individual } \\
\text { cost/visit }\end{array}$ & Rp. 573.529 & $\begin{array}{l}\text { Average costs } \\
\text { incurred by } \\
\text { tourists to } \\
\text { Kolbano beach }\end{array}$ \\
\hline $\mathrm{B}$ & $\begin{array}{l}\text { Assumed number } \\
\text { of visitors/person }\end{array}$ & $18.500 /$ orang & $\begin{array}{l}\text { Tourist visit } \\
\text { data to } \\
\text { Kolbano Beach } \\
\text { in 2019 }\end{array}$ \\
\hline $\mathrm{C}$ & $\begin{array}{l}\text { Estimated } \\
\text { Economic Value } \\
\text { (IDR/ year) }\end{array}$ & $\begin{array}{l}\text { Rp. } \\
10.610 .286 .500\end{array}$ & $\mathrm{C}=\mathrm{A} \mathrm{B}$ \\
\hline
\end{tabular}

Source: Primary Data 2020.

The economic value of the Kolbano Beach tourist attraction is calculated based on the travel costs incurred by tourists for one visit. Based on the research results presented in Table 3, the economic value of Kolbano Beach is Rp. 10,610,286,500, / year. The total revenue that can be obtained by the manager is only from the entrance ticket fee of Rp. 18,500 / person, is Rp. 573,529 , -. The total revenue received by the manager has exceeded the annual budgeted target of Rp. 8,100,000,000. The value of the travel costs of each tourist attraction is different. Factors that can affect the value of the travel costs of a tourist attraction, such as the natural beauty of the tourist attraction offered, accessibility to the location of the tourist attraction, facilities and infrastructure available at the tourist attraction and the distance between the location of the tourist attraction and the area of origin of the tourists According to Putera and Sallata [7], the economic value of Kolbano beach ecotourism as a tourist area from both domestic and foreign tourist visits is IDR 2,422,750,000. This is also reinforced by Khoirudin and Khasanah [8] that based on the results of research conducted with the intent and purpose of estimating the economic value of the Parangtritis Beach object, it was found that the economic average value of Parangtritis Beach was IDR 14,605,101,491 per year. Based on the classification of the value of travel costs, it is known that transportation is the biggest cost incurred by tourists. The means of transportation used by tourists to reach the location of tourist objects are cars, motorbikes and buses. Tourists who use motorized transportation have a relative travel cost small when compared to tourists using cars or buses. According to Subardin [9] that for individual or two-wheeled visitors using a two-wheeled motorized vehicle, the tourism costs incurred are relatively small. This is also explained by Tambunan et al. [10] that the travel costs incurred include transportation costs, consumption costs, documentation costs and other costs such as parking fees and ticket fees. Transportation costs are the most valuable costs so that they greatly affect the amount of travel costs.

3) Perceptions of Kolbano Beach tourists

- Perceptions of Kolbano Beach Tourists on Conditions of Tourist Attraction The calculation of the perception of tourist comfort on the condition of the attractiveness of Kolbano Beach is:

$\mathrm{NN}=\mathrm{RbSr} \times 100 \%=50+36100 \times 100 \%=86 \%$ (excellent Category)

- Perception of Kolbano Beach Tourists on Beach Facilities The calculation of the perception of tourists comfort towards Kolbano Beach facilities is:

$\mathrm{NN}=\mathrm{RbSr} \times 100 \%=49+18500 \times 100 \%=51 \%(\mathrm{bad}$ category)

- Perceptions of Kolbano Beach Tourists on Beach Managers The calculation of tourist comfort perceptions of Kolbano Beach managers is:

$\mathrm{NN}=\mathrm{RbSr} \times 100 \%=45+10100 \times 100 \%=55 \%(\mathrm{bad}$ category)

- Perceptions of Kolbano Beach Tourists on the Desire to Come Back The calculation of tourists' comfort perceptions of the desire to come back is:

$\mathrm{NN}=\mathrm{RbSr} \times 100 \%=53+31100 \times 100 \%=84 \%$ (excellent Category) 


\section{CONCLUSION AND RECOMMENDATION}

\section{A. Conclusion}

Based on the results of the research that has been done, it can be concluded that the potential possessed by Kolbano Beach includes the beauty and cleanliness of the beach, coral clusters, lagoons, beautiful rocks, white sand, and seawater are in the very good category, inadequate facilities, and infrastructure, management services. This is not good, and the potential for community cultures such as traditional ceremonies and tourism events is still low. In calculating the Kolbano Beach tourism object's economic value with the travel cost approach, the results are Rp. 10,610. 286,500 / a year with an average individual travel cost of IDR 573,529 / visit.

\section{B. Recommendation}

Based on the above conclusions, recommendations given to improve tourism facilities and infrastructure and support for Kolbano Beach tourist destinations, repair toilets and procurement of prayer rooms and canteens or restaurants, and increase tourist events in enlivening Kolbano Beach tourism activities.

\section{ACKNOWLEDGMENT}

This study was supported by DIPA funding from Kupang State of Polytechnic. We are gratefully thank for the financial support.

\section{REFERENCES}

[1] C.U. Mayasari, "Strategi Pengembangan Pantai Wediombo Kabupaten Gunungkidul,” Jurnal Khasanah Ilmu, vol. 8, no. (1), pp. 65-71, 2017.

[2] I. Idris, "Estimasi Nilai Ekonomi Total (Total Economic Value) Sumberdaya Alam Dan Lingkungan Danau Singkarak," Bumi Lestari Journal of Environment, vol. 13, no. (2), 2013.

[3] S. Margareta, Hubungan Pelaksanaan Sistem Kearsipan Dengan Efektivitas Pengambilan Keputusan Pimpinan. [Skripsi]. Bandung: Fakultas Ilmu Pendidikan Universitas Pendidikan Indonesia, 2013.

[4] N. Sulistyono, Pengantar Ekoturisme: Editor Buku Oding Affandi. Medan: Buku Panduan Praktik Pengenalan dan Pengelolaan Hutan Departemen Kehutanan, Fakultas Pertanian, Universitas Sumatera Utara, 2007.

[5] A.B. Prayuda, F. Purwanti, dan D. Wijayanto, "Potensi Pengembangan Wisata Air di Waduk Jatibarang, Semarang Berbasis Nilai Ekonomi," Journal of Management of Aquatic Resources, vol. 6, no. (2), pp. 103110, 2018.

[6] BAPPEDA Propinsi Nusa Tenggara Timur, 2014.

[7] F.H.A. Putera dan A.E. Sallata, "Valuasi Ekonomi Sumberdaya Di Teluk Palu, Kota Palu, Provinsi Sulawesi Tengah,' Jurnal Kebijakan Sosial Ekonomi Kelautan dan Perikanan, vol. 5, no. (2), pp. 83-87, 2015.

[8] R. Khoirudin dan U. Khasanah, "Valuasi Ekonomi Objek Wisata Pantai Parangtritis, Bantul Yogyakarta," Jurnal Ekonomi dan Pembangunan Indonesia, vol. 18, no. (2), pp. 152-166, 2018.

[9] M. Subardin, "Valuasi Ekonomi Menggunakan Metode Travel Cost Pada Taman Wisata Alam Punti Kayu Palembang," Jurnal Ekonomi Pembangunan, vol. 9, no. (2), pp. 81-89, 2011.

[10] E. Tambunan, S. Latifah, dan P. Patana, "Analisis nilai ekonomi obyek wisata alam di Kabupaten Samosir, Provinsi Sumatera Utara (studi kasus pemandian air panas di Kelurahan Siogung-ogung, Kecamatan Pangururan)," Peronema Forestry Science Journal, vol. 2, no. (2), pp. 80-84, 2013. 